Article

\title{
The Humanities as Contradiction: Against the New Enclosures
}

\author{
Christopher Breu
}

Department of English, Illinois State University, Normal, IL 61790-4240, USA; cdbreu@ilstu.edu

Received: 13 June 2018; Accepted: 13 July 2018; Published: 17 July 2018

\begin{abstract}
This essay begins by surveying our current moment in the humanities, diagnosing the language of crisis that frames much of the discourse about them. It argues that the crisis is a manufactured economic one not a symbolic one. The problems with many recent proposals-such as the new aestheticism, surface reading, and postcritique-is that they attempt to solve an economic crisis on the level of symbolic capital. They try to save the humanities by redisciplining them and making them mirror various forms amateur inquiry. I describe these approaches as the new enclosures, attempts at returning the humanities to disciplinarity with the hopes that administrative and neoliberal forces will find what we do more palatable. Instead of attempting to appease such forces by being pliant and apolitical, we need a new workerist militancy (daring to be "bad workers" from the point of view of neoliberal managerial rhetorics) to combat the economic crisis produced by neoliberalism. Meanwhile, on the level of knowledge production, the humanities need to resist the demand to shrink the scope of their inquiry to the disciplinary. The humanities, at their best, have been interdisciplinary. They have foregrounded both the subject of the human and all the complex forces that shape, limit, and exist in relationship and contradiction with the human. The essay concludes by arguing that the humanities, to resist neoliberal symbolic logics, need to embrace both a critical humanism, and the crucial challenges to this humanism that go by the name of antihumanism and posthumanism. It is only by putting these three discourses in negative dialectical tension with each other that we can begin to imagine a reinvigorated humanities that can address the challenges of the twenty-first century.
\end{abstract}

Keywords: humanities; neoliberalism; crisis; humanism; antihumanism; posthumanism; new enclosures; bad workers; postcritique; new aestheticism; surface reading; new formalism

\section{The Long Crisis of the Humanities}

The humanities have been in crisis for as long as I have been a part of them. Having gone to college in the late 1980s, I remember a number of the professors at my private, conservative, undergraduate institution warning their classes about the dangers to the profession represented by the new theoretical anti-humanisms, the new novels about nothing, or both. In each of these narratives, the humanities were seen as colluding in our own demise by engaging in theoretical approaches that were hostile to our mission or studying texts not worthy of the same. Of course, when I later left for my radical, public, Ph.D. program on the West Coast, the humanities seemed anything but intellectually bereft. Indeed, it was the work enabled by new theoretical approaches such as cultural studies, poststructuralist critique, and a global Marxism that felt profoundly energizing, radicalizing and renewing. If there was a crisis narrative during this time, it was the dangers posed by a conservative reaction, working to rollback or forestall the work done by these new approaches.

Similarly, when I began my current position in a Midwestern, mid-tier, state school in 2000, it too presented an interdisciplinary (or maybe intradisciplinary is more precise) challenge to business as usual in the humanities. Conceived as an "English Studies" program, my current departmental home 
worked to produce knowledge and theory that cut across the various subdisciplines such as literature (including children's literature and cultural studies), rhetoric, composition, creative writing, technical communication, English education, and linguistics. Perhaps more importantly, the department worked to undo the implicit hierarchy of knowledge that was central to most formations within English departments. Thus literature was interrogated for the way in which it privileged the (always already class-based) position of disinterested aesthetic contemplation and non-instrumental theorization, while other fields, such as composition and technical writing, were seen as both sites of exploitation, where the dirty, semi-vocational work of teaching writing got done, and spaces of greater intellectual honesty, because they didn't suppress their relationship to the vocational and workerist dimensions of our field. Most of this challenge was symbolic, of course. It's not like tenure-line professors were suddenly lining up to teach introductory writing classes. Still this critique represented an important challenge to intellectual business as usual in the English department. The potential crisis here was redisiciplinization, one that would return the field to its hierarchical, liberal humanist norm.

Of course, in contrast to the slowness of academic knowledge production (a slowness which is itself being challenged in the present by developments such as the growth of academic journalism, the academic use of social media, the emergence of small books and alternative arrangements to peer review), the situation of a given field changes rapidly, particularly under the fiscal and institutional reshapings produced by neoliberalism. ${ }^{1}$ Thus, what seemed like literature's and cultural studies's clear dominance at the turn of the twenty-first century has transformed into their seemingly vestigial status a decade and a half on. Literary studies may still have a privileged position in terms of the forms of symbolic capital associated with intellectual hierarchies, but in terms of economic capital, it is clearly on the decline. Moreover, after a period of great intellectual productivity, cultural studies has become moribund in the last ten years (being outflanked by the material turn and the dynamic work happening in media studies). Striking, too, in this context is the splitting off of rhetoric from composition. As literary studies becomes vestigial, the work done by theory (as literature's metadisciplinary other) becomes taken up by rhetoric, which newly wants to dissociate itself from what is seen as the mere vocationalism of composition.

In presenting these different narratives of disciplinary transformations and attendant crises, I think it is important to note how crisis narratives, particularly when they are applied to what Bourdieu describes as various forms of "symbolic capital," are bound to specific institutional positions and commitments (Bourdieu 1984, p. 291). It is only from the point of view of an earlier institutionalized, mid-century humanism that the antihumanist interventions of theory and the postmodern novel appear to be the death-knell of literary studies. Similarly, it is only from the already institutionalized, if also perhaps recently attenuated, position of theory in the contemporary academy that a newly ascendant field of rhetoric appears as an usurper (if one that has a deep historical lineage). It is for this reason that I begin this paper with an account of my own institutional formation and position. It is perhaps a version of situated knowledge praxis, as advocated by Donna Haraway, but rather than marking my subjective positionality, I think it is more pertinent in relationship to the conversation that follows (and perhaps not only in this context) to mark my institutional positionality (Haraway 1998). Where we teach, what we research, what position we hold in the hierarchy of the profession, where we are in our careers, what intellectual and professional allegiances we hold, all affect what we perceive as representing potential or existing crises in the field. For the record I am a full professor in the English studies department described above. I mostly teach classes in theory and contemporary literature and culture in the United States. My theoretical allegiances (as will become clear further on) are to a non-doctrinaire Marxism as it mixes with ecocritical scholarship and work in the new materialisms. In what follows, then, my account of the humanities, its current state, and its future possibilities needs

1 My thinking about neoliberalism in this essay has been shaped by David Harvey, A Brief History of Neoliberalism (Harvey 2005); The Birth of Biopolitics: Lectures at the College de France (Foucault 2010); and Undoing the Demos: Neoliberalism's Stealth Revolution (Brown 2015). 
to be understood in relationship to my institutional and intellectual positionality. Hopefully, what I say isn't confined by that positionality and can speak to those in other positions. It is inevitably, however, shaped by it. Depending on one's position, another name for crisis might just be change. When you are a part of a specific intellectual hegemony and institutionalization, the young barbarians or Hegelians at the gates appear as a threat to one's specific institutional position or hegemony.

This subjective construction of the notion of a crisis is perhaps why Paul Jay, in a recent book on the humanities puts the word "crisis" in quotes (Jay 2014). I think Jay gets this both exactly right and exactly wrong. As I have just argued, I agree with Jay to the extent that often what we narrate as crisis is just a changing of the intellectual guard or the workings of intellectual fashion. Sometimes what is new represents a genuine leap forward in terms of knowledge (one thinks of the original interventions made by cultural studies, or the turn to things material in the present moment) and sometimes it represents a retreat from the political work of earlier moments. Either way it is often perceived and narrativized as a crisis by those holding institutional power.

There is another crisis to which we need to attend, one that is about economic capital rather than symbolic capital, however. Here the quotes come off. In arguing this, I am not suggesting that such a crisis in economic capital is not somehow manufactured. As Marc Bousquet has cogently demonstrated, it is, like the many austerities of our present moment, thoroughly manufactured (Bousquet 2008, pp. 186-210). Yet, it has a different kind of material force than the perceived crises in symbolic capital. Frank Donoghue argues that this crisis should also be put in quotes, since it too is manufactured and doesn't represent a crisis for higher education in general, merely the professorate (Donoghue 2018, p. 1). Donoghue is surely right about this, but I think it is important to describe the manufactured crisis in economic capital (i.e., the slow-death by austerity and non-replacement of tenure-line faculty) as a real threat rather than an imagined one to professors and teachers throughout higher-education. Indeed, Donoghue demonstrates that the destruction of tenure-line professors and transformations in definitions of intellectual property do not bode well for non-tenure-track professors as well (Donoghue 2018).

There is of course a relationship between symbolic and economic capital, but it is a mediated one. One of the problems with current rhetorics of crisis is that they often abjure attending to these mediations and the partial autonomy of each sphere. More significantly, as I will detail further in a moment, they are organized around a misguided conception of attempting to fix in one sphere problems that are primarily of another sphere.

There was another crisis which was invoked by my professors when I was studying at my undergraduate institution. This was the crisis of the academic job market. If the rhetoric of crisis has followed me around from institution to institution, the materiality of this crisis, and its ever deepening force, has haunted me throughout my career. On one level, I have survivor's guilt. I realize that I am one of the lucky and privileged ones who has managed to secure a tenure-line job and make it to full professor. If, as Christopher Paul argues, video games and video game culture are in part about a toxic conception of meritocracy, then such a conception is also true of the academic job market (Christopher 2018). We take the mix of class, social privilege, luck, and unequally recognized hard work as an index of meritocracy, imagining those that who have tenure-line jobs and occupy powerful, gate-keeping positions within the profession have earned it. This belief is structured by what Slavoj Žižek describes as the logic of the fetish (Žižek 1989, p. 48). Even when we know the market for jobs and publications not to be a meritocracy, we continue to act as though it were. Moreover, this action structures our unconscious belief and sutures us to a system that does not finally benefit us (in terms of working conditions, the time devoted to work, or any sense of solidarity with our fellow workers).

The video game metaphor is apt in other ways. Often when I make it to a new stage of academia, I feel like a video game character running through a level with the walls and bridges collapsing right behind me. Each time, I feel like I barely make it through. At some point, though, I won't make it through. The bridge will collapse, or the floor will open up below me, or I will be shot down by various enemies (conservative trolls, neoliberal administrators, austerity minded politicians, newly 
emboldened fascists, perhaps rightfully aggrieved colleagues and students, take your pick). As I drop I see the scattered bodies of other fallen aspirants, other promising scholars and teachers. Moreover, even if I do make it through, looking behind me what I see is the unfairness of the whole process, the destruction it leaves in its wake, and the ever growing accumulation of those who did not make it through. The precarious existence of the videogame becomes the precarity of everyday life in the neoliberal academy, even for the tenured.

\section{Distinguishing Between Crises}

So how do we change this dire situation? While I have issues with the emergence of what is being termed "postcritique", as I will enumerate below, something that both Bruno Latour and Rita Felski are right to argue is that it is much easier to critique than it is to build something affirmative (Latour 2004; Felski 2015). Thus, after the grim videogame metaphor, I want to spend most of the rest of this essay articulating what we do well, what we can do better, and what concrete steps should be taken to combat the manufactured crisis of actual capital in relationship to the humanities. I will also stage a defense of interdisciplinary knowledge as a version of the humanities at their best. In terms of interdisciplinarity, I do not mean an abandonment of disciplinary knowledge, but rather a thoughtful and innovative combining of the knowledge of one discipline with another or multiple others. Such a conception doesn't produce a transdisciplinary fusion, but rather a dialectical model attendant to the differences between disciplines as well as sites of partial convergence and productive tension. Examples of such interdisciplinary work in the present would be the attention to political economy as it intersects with literature and culture in the work of Annie McClanahan and Anna Kornbluh. Another example would be all the work that has been done in critical science studies over the years, from Donna Haraway and Bruno Latour to Karen Barad and Clare Colebrook.

One of the dangers that I see in our present moment is an attempt to solve what is a structural and systematic economic crisis on the level of symbolic capital. One of the illusory promises of new methodologies in the humanities is that if we make what we produce more symbolically appealing and less contentious, we will somehow be able to attract the economic capital that has been divested from us. This, of course, is a neoliberal solution to a problem produced by neoliberalism: if we just improve our human capital then we will be rewarded by the market. Not only does such a fantasy solution misapprehend the forces arrayed against the tenure system and the humanities more generally at the moment, forces that are not interested in sustaining the humanities in their current form, but are instead looking for various ways to privatize, produce what Benjamin Ginsberg calls the "all-administrative university," cut skilled labor costs, and reshape most fields in the humanities as service fields, it also confuses the different crises with which we began (Ginsberg 2011, p. 38).

Paul Jay is right to put the recurrent crises of symbolic capital in the field in quotes. A professor doing Jungian archetypal criticism of British poetry does not have the same symbolic cachet as they once did, while a theorist of multiculturalism in technical writing may find their cachet on the upswing. The technical communication theorist may find the current profession more rewarding and offering of job opportunities than a young version of the archetypal critic (if such a thing exists anymore). But this shift in symbolic emphasis, although open for ideological critique, does not a crisis make. It is a shift in symbolic value, but not a crisis in the legitimation, sustainability, and economic support of the field as such.

It is just such an economic crisis that we are currently battling, however. This is a crisis pure and simple. In battling it, I think we need to fight this crisis head on and on the level on which it is happening: in terms of economic capital and our own position as workers. The value of symbolic capital depends finally on the workings of actual capital, however mediated this relationship is. Thus, the fantasy that we will solve the current crisis exclusively on the level of symbolic capital is precisely that: a fantasy. We imagine if we just get our symbolic capital right maybe the forces that are destroying us will leave us alone or even support us. It is fundamentally a fantasy of being a good, compliant worker and like all such fantasies, it has very little to do with the realities of capital accumulation. 
In making this argument, I am not saying that the work we do is unimportant. It is crucial to imagining a better and more just future (see my proposal for the future of the humanities below), I am merely arguing that it is idealist to imagine that our individual and symbolic endeavors will somehow solve a larger economic crisis. In the next, brief, section I posit what such a fight might look like. I see this section almost as a manifesto-the manifesto of the bad worker. If you want to know how we might solve or at least fight against the economic crisis in the academy at present, here is my manifesto. These actions may not be enough either, but they are at least a material start to responding to a material crisis. After stating the manifesto, I will get back to straightforwardly intellectual matters. What I won't do is look to individual symbolic approaches to solve primarily economic problems.

\section{In Praise of Bad Workers}

In order to combat the current economic threat to what we do, rather than being good workers, we need to be bad ones. Of course, we need to be good scholars, teachers, writers, thinkers, and mentors. Being a bad worker precludes none of this. What it does preclude is apolitical forms of professionalism and adherence to the status quo. Bad workers unionize, especially across craft lines. Bad tenure-line workers recognize their non-tenure-track colleagues as colleagues and vice versa. Bad workers refuse to be pitted against fellow workers. Bad workers refuse to adhere to disciplinary constraints. Bad workers refuse the academic bargain that we are able to think like radicals as long as we continue to act like neoliberals. We will dare to act the way we think. Bad workers refuse the culture of excellence that Bill Readings so aptly described in the 1990s and continues, as a central tenet of the neoliberal structuring of the academy, into the present (Readings 1996, pp. 21-44). Bad workers refuse to be apolitical. Bad workers insist on a voice in university, state, national, and global politics. Bad workers refuse to be bound by ethics and compliance tests, when such tests are designed to curtail the work done by bad workers. Bad workers refuse best practices when such practices are used to discipline bad workers. Bad workers refuse encroachments on academic freedom not only when they affect tenured professors but when they target non-tenure-track professors, staff, and students. Bad workers work for a vision of the university as a public institution and as both a commons (with agreed upon rules of sharing and collective production) and an undercommons (that interrogates and challenges such rules) in Stefano Harney's and Fred Moten's formulation (Harney and Moten 2013). They struggle for a workerist rethinking of the academy that is about the recognition of all the different forms of work the academy as commons enables.

\section{Against the New Enclosures}

So now that we have an account of how to combat the current economic threats to the university, we are in a better position to assess new intellectual developments in the field. Such intellectual developments will not be unduly burdened with somehow trying to solve the current crisis of the humanities and higher education more generally. Instead we can measure them for what they contribute to the work of the humanities at their most visionary and risk taking and how much they are able to resist the kinds of depoliticizing championed by the competitive, privatizing, and individualist ethos of neoliberalism. In making this argument, I am not arguing that there is no relationship between the intellectual work that we do and the larger forms of political-economic contradiction within which it functions. The account of such a relationship is central to Marxist theory as such. Yet this relationship manifests in symptomatic readings and in the unconscious logics that structure a field as much as in its consciously created content. It is also a product of complex mediations, ones that need to be theorized in their complexity. Such a reading doesn't imply an equally reversible causality between field and political economy. A simply reversible account of causality is deeply idealist. I am not arguing that what we do in a given field has no relationship to the significance of our work going forward (indeed, in this essay's conclusion, I will propose a model for political scholarship in the contemporary humanities, one that can help us address the ecological and political-economic contradictions and 
violence of the present), but I think it is idealist to think that the content of our work can equally shape in turn the political-economic context from which it emerges.

This is one of the limitations of Caroline Levine's generally invigorating work in the new formalisms. Even as she rightly criticizes new historicism for its lack of theorizing form and its treatment of text and context as essentially the same and equally causal, she makes the same move with her notion of form. Aesthetic forms shape political forms as much as the latter shape the former: "As different forms struggle to impose their order on our experience, working at different scales of our experience, aesthetic and political forms emerge as common patterns that operate on a common plane" (Levine 2017, p. 16). Leaving to one side the question of their immanence on a common plane, it is not at all clear to me that aesthetic and political forms can be conceptualized as functioning with the same force. I'm not sure the causal relationship is so simple or easily reversible. This is not to argue that aesthetic forms do not do important cultural work; they clearly do, whether this work is representational, historical/genealogical, or speculative. It is to suggest, though, that aesthetic forms and larger political and economic structures have different degrees of force and power, and exert different kinds of causality.

As Levine's "new formalism" indicates, one of the hallmarks of our present moment in the humanities is the emphasis on various "new" approaches, what is also described in the language of "turns". To name only a few, these include the new materialisms (also known as the material turn); the new formalism, the new aestheticism, the posthuman turn, and the affective turn. Moreover, there are approaches, such as postcritique, surface reading, and speculative realism, that propose to revolutionize knowledge in the humanities (primarily English, but not exclusively) by arguing against long held methodologies (i.e., critique, close reading, correlationism, etc.). This emphasis on newness itself is a symptom of the neoliberalization of the humanities. The demand to innovate is ever more insistent as is the competition around ever scarcer forms of symbolic and economic capital. This competition produces scholars who work to maximize their human capital in order to leverage it into ever fewer job and traditional-publishing opportunities. The competition around scarce resources leads to inflated scholarly claims that promise a revolutionary transformation of the field as such. Moreover, the rhetoric of neoliberalism is often about conceptual innovation (look at the rhetoric of tech companies) as much as it is about Readings's conception of deracinated excellence (Readings 1996, pp. 21-43). Even the publishing environment for academic work has shifted in such a context. Not only have all but the top academic presses found themselves pushed out by for profit companies like Palgrave, Routledge, Ashgate, and Bloomsbury, but they are also feeling competition in relationship to the small book market associated with Repeater Books, Zero Books, etc., some of which abjure peer review and which tend to publish speculative ideas very swiftly. Indeed, Minnesota, Stanford, and Palgrave have created (peer reviewed) versions of similar books in their Forerunners, Brief, and Pivot series. Moreover, the growth of academics writing journalism (often for free or for relatively cheap) for places like Jacobin, Salon, and the L.A. Review of Books, also suggests that the rhythms and demands of academic work are changing in the present. These changes have utopian as well as ideological possibilities. The small books tend to sell in greater numbers than the conventional academic monograph, even from presses, like Duke and Minnesota, which maintain a strong sales market for their paperback monograph offerings. At their best, these new publishing contexts create the return of the figure of the public intellectual, whose disappearance was much bemoaned in late-twentieth-century theory. At their worst, though, they not only work to undermine other professions (note the near destruction of journalism as a profession via the replacement of professional staff with freelance writers, many of them academic), and provide uncertain publishing contexts for junior scholars seeking promotion, but also orient academic knowledge around ideas of accelerating, and thus ever less thought-through, innovation.

This drive for innovation is of course also tied to the generation of intellectual property, in which intellectual labor is being privatized, accumulated (via dispossession), monetized, and extracted in new ways. If academia under neoliberalism is fundamentally about the transformation of the labor of 
the university in the moment when intellectual labor is one of the leading, if unstable, sectors of the global economy, then it should not be surprising that even the relatively underfunded and increasingly neglected humanities are reconceptualizing themselves in relationship to the language of intellectual innovation and ownership. This language is present not only in the emphasis on field redefining "turns" or forms of "newness" but also in terms of what I want to describe, with some irony, as the new enclosures, or attempts re instituting disciplinary boundaries and uniqueness. The major enclosures, as Donoghue argues, are around who owns teaching materials and research, but conceptual enclosures also abound (Donoghue 2018, pp. xxiv-xxv). The latter redrawings of borders are also attempts at rebranding.

During the expansionist phase of neoliberalism that characterized the 1980s and 1990s, the humanities were defined by the challenge that theory represented to disciplinarity and various canons. This was the era of the star system, when the academics with the most human capital (even if the substance of their scholarship was explicitly anti-capitalist) were given privileged, often endowed positions at the same time that the profession increasingly relied on non-tenure-track and graduate student labor. As with neoliberal transformations in the United States in general, those in the upper echelons of professions and those with the most human capital (in Foucault's terms) benefitted, while those occupying lower rungs in the professions and/or who lacked human capital suffered worsening and more unequal working conditions. In terms of the constitution of knowledge in different disciplines, theory was privileged as was interdisciplinarity. Moreover, this was an expansionist version of interdisciplinarity, in which theory challenged various disciplinary divisions and boundaries, and produced a metadiscourse that echoed the metafiction of the same era. While there was much that was wrong about this moment in terms of the economic restructuring of the academy and, as I have argued elsewhere, the often exclusionary emphasis on language and culture, its embrace of theory and interdisciplinarity represented a powerful development in English departments and in the humanities more broadly. For one thing, it worked to undo the reification of knowledge in various disciplines that, as Adorno and Horkheimer argue, transformed the critical rationality of the early Enlightenment into the instrumental rationality central to monopoly capitalism (Horkheimer and Adorno 1999, pp. 1-34). The high moment of theory and interdisciplinarity in the 1990s dared again to ask critical questions of the forms of rationality and knowledge that had been institutionalized within the modern university. It produced an antifoundationalist discourse, which, for whatever its problems and incoherencies, worked to query the violent foundations of modernity and the institutions central to it. The work of theory, while less celebrated, continues apace in the present, and it does so in ways that are rewriting the antifoundationalist and culturalist limits of (aspects of) 1990s theory. Yet, there has also been a disturbing turn away from this political work and toward an apolitical redrawing of disciplinary boundaries. It is this I am calling the "new enclosures". Here, I would include the work that can be situated under the rubric of postcritique, the new aestheticism, and surface reading. Ironically, since it is about the enclosure produced by forms, I would not include the new formalism, which, although I registered some of my concerns about it above, does not turn away from the political although it does from interdisciplinarity.

The new aestheticism is the older movement here, and is perhaps addressed most easily. It is partially an affirmative account of theorizing the relationship of affect to aesthetics in order to conceptualize a radical and democratic conception of the aesthetic. It also, however, reads as a rearguard movement that tries to put literary studies back into the framework that it existed within before the intervention made by cultural studies. Isobel Armstrong defines the new aestheticism as challenging the politics of the anti-aesthetic as articulated by Terry Eagleton, Pierre Bourdieu, and a range of cultural studies practitioners (Armstrong 2000). Her framework relies on a Kantian conception of the aesthetic as a subjective universal. One of the problems with cultural studies was its largely wholesale rejection of the aesthetic as inherently elitist. Armstrong's work and the work of other affect theorists such as Sianne Ngai and Lauren Berlant, as well new materialist work by Brian Morton, Clare Colebrook, and others, affirms the necessary dimension of the aesthetic as the form of 
knowledge involved in apprehending an object or text broadly conceived (although Graham Harman's account of an object-oriented aesthetics seems merely to repeat new criticism in a another form). ${ }^{2}$ This much of a return to aesthetics is necessary, even crucial. The new aestheticism's emphasis on the autonomy of the literary object as articulated by Armstrong and Harman, however, and its emphasis on the damage done by most forms of social (rather than merely aesthetic) critique seem to long for the moment in which the canon debates and political-economic analysis as such were not yet part of the study of literature. As, Damien Searls affirmatively puts it in his manifesto for the movement, new aestheticism wants art "merely to be beautiful" (Searls 2008). Some of the same impulses are evident in the more recent movements, postcritique and surface reading.

At its best, postcritique wants to argue against what Eve Sedgwick called, at an earlier moment, paranoid reading practices and promote reparative readings (Sedgwick 2003, pp. 123-52). Yet, while turning to the positive is necessary in any of a number of ways, from maintaining the transformative force of utopian thought to more practical proposals (such as my bad worker proposal above), postcritique proposes to attenuate the work of critique. It instead promotes an idea of attending to the pleasures of the text and of affirming the "incandescent extraordinary, sublime, and utterly special" (Felski 2015). It also suggests that such a practice will affirm the pleasure students find in the act of reading. Certainly, we don't want to destroy pleasure, but this feels like an abandonment of political work of all kinds in the humanities and an elevation of amateurism to a new model of criticism. It reads like a willful abandonment of thirty plus years of professional commitments to engage the politics of the humanities as such.

The same can be said for surface reading. Surface reading also turns against the concept of professionalism in literary studies. It argues for a modes of reading that "attend to the surface of texts, rather than plumb their depths" (Best and Marcus 2009). Echoing the new criticism in its emphasis on engaging the text in isolation, it also jettisons the new criticism's investment in literary hermeneutics, focusing merely on what can be gleaned from the surface of the text itself. While the antihumanism of Foucault and Deleuze often argued against models of depth, they did not do so in relationship to the self-evident surface meanings of texts. Their point was more about the metaphorics of depth and the conceptualization of the relationship between text and context. It was also a rejection of a kind of interpretive vanguardism, or the idea that the interpreter could speak unproblematically on behalf of the buried truth and/or the oppressed masses (Foucault and Deleuze 2006). While Deleuze and Foucault's arguments have their own problems (it is unclear how one can interpret anything without some sort of hermeneutic framework and, at its worst, their method can become a refusal of the most radical potential of theory to transform and undo the ideological stasis of what exists), it doesn't abandon the work of critique as such.

The claims of surface reading do not strive towards radicalism. Instead, surface reading is designed to appeal to the kind of amateurism that is central reading literature and engaging popular culture in the present, whether it is various on-line forums, the practice of fan fiction, or the emergence of young adult fiction as a market phenomenon. All of these latter developments have much to recommend them. Indeed, I am enough of a cultural studies scholar to think that each of them has real merit and is worthy of study. What I would argue against, as would the most valuable versions of cultural studies (say the work of Stuart Hall or Janice Radway) is somehow modeling our interpretive model to be as content or surface oriented as we imagine amateur reading practices to be. ${ }^{3}$ We teach something crucial in literary and cultural studies: the ability to read cultural texts

2 I am referring to the following texts here: Our Aesthetic Categories: Zany, Cute, Interesting (Ngai 2012); Cruel Optimism (Berlant 2011); Hyperobjects: Philosophy after the End of the World (Morton 2013); Sex after Life (Colebrook 2014); "The Well-Wrought Broken Hammer" (Harman 2012).

3 The work of Radway and especially Hall is too voluminous to cite here, but two examples of the kind of complex engagement with popular culture that is neither patronizing nor bereft of critique would be: Janice Radway, Reading the Romance: Women, Patriarchy, and Popular Literature (Radway 1991); “Encoding, Decoding” (Hall 2008, pp. 907-16). 
critically and complexly as products of a society that is not reducible to its literary and cultural representations. This approach shouldn't be jettisoned in the desire to somehow be more appealing to what are imagined to be amateur approaches to reading and culture. Indeed, any real attention to on-line debates would recognize that critique and the hermeneutics of suspicion are alive and well outside of the academy. As, Eleanor Courtemanche has persuasively argued, cultural studies analysis has migrated from the academy to popular culture itself in recent years (Courtemanche 2016). Yet it has changed character as it has moved on-line, becoming more reactive, more idealist, and more oriented around the politics of representation in a manner that assumes representation is somehow adequate to what is. What has been lost is the powerful critiques of the limits of representation itself that the best of cultural studies and especially Marxist work enacted. As the hashtag has it, "\#RepresentationMatters" but what is occluded, obscured, or minimized by representation matters more. This insight is what the interdisciplinary approach to literary and cultural studies can provide, especially to forms of on-line critique that are admirable in their fierceness, even as they could be more tempered in their attention to the material contradictions in which representation itself functions.

In the present, post-economic crisis moment of neoliberal austerity and the privileging of accumulation by dispossession, it is not surprising that we have seen a retreat to disciplinarity and to some methodologies that want to promote a kind of amateurism in literary studies. These are the new enclosures, but rather than the aggressive enclosures of the eighteenth century that were part of Marx's account of primitive accumulation, or the privatizing enclosures of accumulation by dispossession in our neoliberal present, these are defensive enclosures. While they may certainly be part of a privatizing of the public university, and the desire for the old position of the gentleman scholar (of all genders) is evident in the work of the new aestheticism, in general they are defensive rather than aggressive closures. They seem to assume that if we stay within our walls and play nicely (telling people what we assume they want to hear about literature and culture) we will be allowed to continue to exist. Of course such a position imagines the structures of cultural and symbolic capital to be what they were back when many current professors did their undergraduate work. It also imagines that solutions to economic crises are somehow cultural.

Rather than capitulate to such forms of disciplinary conservatism I want to conclude with three different propositions that can be a spur to on-going interdisciplinary work. In doing so, I want to affirm interdisciplinary work. Interdisciplinary doesn't mean transdisciplinary. It still requires, in fact insists, on disciplinary knowledge. What it resists is the idea that any discipline represents a privileged access to the truth or to the real. It recognizes that disciplines are (necessary) reifications of knowledge that need to be imagined as attempts to grasp totality. In attempting to do such critical work, interdisciplinarity is necessary, a crucial feature of non-reified knowledge.

In making the argument that follows, I want to return to humanism itself, recognizing that it has always been at the fraught center of the humanities. I think we need to be dialectical about humanism, but in a way that doesn't resolve the contradictions that accumulate in relationship to it. Rather, we need to be dialectical in a way that emphasizes contradictions. This would be a negative dialectics that doesn't resolve antagonisms but recognizes and affirms them. As Adorno articulates it, such an approach frees "dialectics from ... affirmative traits without reducing its determinacy" (Adorno 1973, p. 1). Thus, I both want to affirm the need to think about totality and recognize the dialectical tensions and antagonisms that necessarily are involved in such a thinking. Borrowing my language from Anna Kornbluh's compelling argument that "we have never been critical" (which in turn echoes while also challenging Latour's We Have Never Been Modern), I am going to assert three statements (Kornbluh 2017; Latour 1993). These statements need to be thought in dialectical contradiction with each other. Taken together they represent a defense of the humanities in all of their theoretical and interdisciplinary force. These three statements are: we have never been humanist; we have never been antihumanist; and we have never been posthumanist. 


\section{We Have Never Been Humanist}

On the face of it, the above seems like an absurd statement. Of course we have been humanist. Humanism has been at the core of what we do at least since an Arnoldian conception of culture, as both a cure for class antagonism and an edification of a philistine middle-class, was institutionalized by the Leavises in England and by the formalist and new critics in the United States. Humanism is everything that the theory revolution was designed to dethrone, with the latter's emphases on antihumanism and, more recently, on posthumanism. Yet, when we invoke humanism we often treat it like a straw person. We take one, relatively conservative, version of humanism and make it stand in for humanism as such. A genuine humanism, one that focuses on all aspects of human life and labor, has an affirmative universalism about it that still has much to offer. There are other historical humanisms than the Arnoldian one. Take, for example, Étienne Balibar's conception of the humanism of Marx (articulated, ironically enough, by a figure usually associated with Althusser's antihumanism):

For, amazingly, neither of those two positions [realism and nominalism] is capable of thinking precisely what is essential in human existence: the multiple active relations which individuals establish with each other (whether of language, labour, love, reproduction, domination, conflict, etc.) and the fact that these relations define what they have in common, the "genus". (Balibar 1995)

As the invocation of "genus" makes clear the humanism invoked here is that of Marx's conception of species being in The Economic and Philosophic Manuscripts of 1844 (Marx 1978, p. 75). This is a humanism that runs counter to Arnoldian humanism and the forms of liberal humanism which it underwrote. Balibar's emphasis, an emphasis that is central to Marxist materialism in general, is on what is produced by and through "active relations." Such a humanism attends to all human relations, not just those that are privileged as elite or central to specific traditions. As Terry Eagleton has recently argued, such an understanding of species being also attends to what is common and shared about human embodiment and experience as well as to the myriad cultural differences that have been so central to academic inquiry in the last thirty years (Eagleton 2016, pp. 22-23). This humanism is thus premised on a universalism, but not one that is ever fully attainable. It is a universalism as a utopian ideal, in which all humans are valued equally and human relationships are affirmed or critiqued for what they are able to construct (systems of education, human flourishing, and collective production on the one hand, and systems of inequality, social control and anti-social violence on the other). This affirmative universalism is central to Balibar's analysis of the double resonance of any kind of rights declaration (Balibar 1994, pp. 39-60). On the one hand, rights are particularistic, they necessarily are inadequate and exclude. On the other hand, however, they always contain the possibility of universalization and radicalization. Rights struggles should always push for a wider and more complete application of what is most radical and just in any given claim.

We have never made good on the promise of this conception of humanism in relationship to higher education, either in terms of access or in terms of the content of what we teach. Cultural studies, with its emphasis on cultural materialism (as the shared production of human life) and its undoing of canons and geographies of value, was an impressive attempt to begin to be adequate to such a humanism. We need to continue to practice its best insights. Rather than an approach to the humanities that shrinks itself back to the aesthetic analysis of the canon of great books or reassert traditional divisions, we need one that engages the complex array of human cultures and human cultural possibility in the present. Not only would such a conception continue to emphasize globality (as the best practices in world literature, postcolonialism, world history, comparative literature, and comparative philosophy have done), but it would also look at the vernacular cultures of global business, popular culture, and everyday life. Such an understanding would produce a conception of the humanities (and cultural studies) that is attentive to what A. Shuresh Canagarajah describes as translingual literacy: "Translingual literacy is an understanding of the production, circulation, and reception of texts that are always mobile; that draw from diverse languages, symbol systems, and modalities 
of communication; and that involve inter-community negotiations" (Canagarajah 2014). Such an understanding of literacy would attend to the fact that in our present global situation, English is spoken more as a second language than a first and intermixes with other languages and meaning systems in ways that are complex and generative. What might an English department look like that took this notion of translingual literacy and the cultures it underpins seriously? What would a comparative literature or linguistics department look like? These are the questions that a vital new humanism would begin to address.

Such a humanism would also take seriously the global and equitable availability of education to all. Such a humanism is worth fighting for. Of course, such a humanism also needs to be put into dialectical tension with the most powerful dimensions of antihumanism and posthumanism. This brings us to our next proposition.

\section{We Have Never Been Antihumanist}

Any humanism worth its salt (or carbon), needs to be thought in tension or contradiction with antihumanism. Antihumanism is, of course, one of the names for the poststructuralist theory revolution. Antihumanism decenters the human subject, but this subject is still the primary locus of this decentering. Yet, I might situate its genesis even further back, as do antihumanists like Foucault, Lacan, Derrida, and Althusser, in the revolution of thought produced by the collective cultural impact of Marx, Nietzsche, Freud, and Darwin. This revolution had the effect of dethroning the liberal humanist subject of the nineteenth century as well as challenging the forms of positivism that were central to intellectual inquiry in the same moment. After these Copernican revolutions, "man" (and I used the gendered term here advisedly) no longer sits at the center of the intellectual universe. Instead, to apply this to the thinkers I invoked above, his centrality is usurped by political-economy, power, the unconscious, and/or natural selection. To tell a brief and woefully reductive story, the structuralists formalized this decentering more fully by locating structure (as imagined in terms of the structuration of language) as the entity that decenters the human (in terms of both agency and knowledge). Poststructuralism, in turn, attended to both the incompletion or contradictory quality of structures and their overdetermination by various forms of power.

In elaborating his vision for an antihumanist historiography, Foucault argues against forms of historicism that produce narratives that are a "privileged shelter for the sovereignty of consciousness" (Foucault 1972, p. 12). He goes on to argue:

Continuous history is the indispensable correlative of the founding function of the subject: the guarantee that everything that has eluded him may be restored to him; the certainty that time will disperse nothing without restoring it in a reconstituted unity; the promise that one day the subject—in the form of historical consciousness—-will once again be able to appropriate, to bring back under his sway, all of those things kept at a distance by difference, and find in them what might be called his abode. (Foucault 1972, p. 12)

Here Foucault emphasizes that a proper antihumanism produces a different historicism, one articulated around dispersion, otherness, and discontinuity. It emphasizes everything that both overdetermines the subject and partially or fully eludes their control, their conscious knowledge, and the forms of representation they employ. If humanism is about everything finally being "restored" to the subject in this account, then antihumanism insists that such a restoration is finally idealist. In humanism, the subject becomes that which is both the source and the final end point of all knowledge. Traditional humanist thinkers transcend historical particularity even as they narrate it. All that stands in opposition to the subject is finally retrievable for and reducible to that self-same subject.

In contrast antihumanism focuses on all of that which overdetermines and/or eludes the subject, including structures and apparatuses (Althusser), institutions and discourses (Foucault), the unconscious and the Real (Lacan, Žižek), the iterative performance of gender (Butler); the body and its relationship to language (Irigaray), and the workings of language itself (Derrida). Thus, 
antihumanism can be seen as fundamentally anti-idealist. It rejects the notion that the subject can fully master that which is set in opposition to it. In doing so, it also rejects the interpretation of Hegel that finally reduces the object to the domain of the subject, difference to sameness, and history to spirit. It instead insists on a history that is not only defined by breaks, recursive structures, and discontinuities, but also is defined by the refusal of subjective mastery and transcendence. It is not only the subject that is deconstructed but the object. It emphasizes that which eludes or exceeds (supplements in Derrida's terms) our concepts of the world in which we operate.

While it may seem that we have lived in the regime of antihumanism for a long time now, it is necessary to fully develop the most radical of its insights. Central to such notions would be attending to what is revealed and can be articulated once the human and the subject is decentered. While cultural studies straddled the divide between antihumanism and humanism, it still was often too human centered-a kind of constructivism in which it was the subject who constructed rather than was constructed and that which existed in opposition to subjects was often undertheorized. Similarly, much of the application of deconstruction and other forms of poststructuralism to literary studies produced a kind of implicit (and sometimes explicit) Kantian idealism in which the subject was still the privileged locus of deconstruction or theorization and alterity of the object and even other subjects was invoked but left untheorized. In the deconstruction of the subject/object dyad, the subject became implicitly privileged all over again, if only because of what Quentin Meillassoux calls correlationism, or the Kantian idea that we only have access to the subjective idea of things and never to the things in themselves (Meillassoux 2008, p. 5).

A true antihumanism would decenter the human subject even more intensely and attend to all of that which both enables and sets limits on its functioning. Such an antihumanism would emphasize the way in which structures and institutions not only decenter the subject, but also create forms of social inertia and repetition. One of the insights that has yet to be fully developed from Althusser is the way that structure and systems of reproduction work to ensure stasis as well as change and function to limit as well as enable social functioning. Similarly, readings of Foucault that give serious weight to institutions, the functioning of biopolitics, and the anatomopolitics of the body, also suggest an antihumanism that is not merely about language, but one that decenters the subject in relationship to various forms of material as well as discursive constraint. Such an account would posit institutions and bodies as material and as having a different status of materiality from that of discourse.

A revitalized antihumanism might produce a Marxism that didn't just emphasize human praxis and labor (although theorizing both are crucial), but also the force and weight of economic, political, and material structures and systems that overdetermine such forms of praxis. Of course, this tension between human praxis and political-economic determination has always been central to Marxism (and this is one reason why I am asserting the need for an unresolved dialectical tension between humanism and antihumanism), but a more developed Marxist antihumanism would not only emphasize political economy, a field which has indeed seen a renaissance in recent years, but also that most taboo of Marxist categories during the cultural turn: infrastructure. In a contemporary world in which code takes on a structuring role, the built environment grows ever more dizzyingly complex, algorithms drive not only social media but much of the financial sector, and the global political economy is ever more massive in scale and operation, a revitalized and rethought category of infrastructure is necessary. Moreover, we may need to think about how we calculate labor, waste, and the production of value in a world in which automation grows, the processing and exploitation of animals is ever more central, and climate change threatens the planet as such. In order to theorize the last, we, of course, need to move from the interdisciplinarity of antihumanism to that of posthumanism.

\section{We Have Never Been Posthumanist}

This claim is hardly surprising given that posthumanism is one of the more recent developments in scholarship. It is ascendant but not yet hegemonic in the humanities. It also is explicitly interdisciplinary, much of its initial genesis taking place within critical science studies. Posthumanism 
addresses all the dimensions of life that were neglected by work in humanism and even in most forms of antihumanism. In contrast to the latter, rather than merely decentering the human, posthumanism focuses on various nonhuman entities, such as animals, ecosystems, and machines, and rethinks the very exceptionality of the human in relationship to them. Nathan Snaza and John A. Weaver define posthumanism as precisely such a turn to the excluded:

Although posthumanisms vary enormously in the specificities of their engagements (and we believe that we are nowhere near discovering all the permutations), they share in turning toward the legacies of humanism and using posthumanist reconceptions of human/animal/machine/thing relations to diagnose how humanism ignores, disavows, and obscures the real relationship between beings and things that make up the stuff of the world. (Snaza and Weaver 2014)

Thus, if antihumanism decentered the human subject to focus on the systems and structures that shape, construct, and overdetermine its relationship to the world, it was still focused on the human subject as the locus of the decentering. Posthumanism on the other hand redefines the human in a non-exceptionalist way. Rather than seeing the human as constitutively different from other animals, forms of materiality, and machines, it posits all of these as crucial entities or domains of contemporary existence, ones that are thoroughly entangled, or to use Stacy Alaimo's language, intertwined in trans-corporeal relations (Alaimo 2010). Snaza and Weaver capture this entanglement in their noun phrase, human/animal/machine/thing. Within much posthumanism, humans are just another species, if one particularly dangerous for other species and life forms. Similarly, the lines between machine and human, body and thing, are thoroughly complicated by various posthumanist or cyborgian embodiments.

Moreover, if, at its most radical, antihumanism pushed against correlationism, most forms of posthumanism break with it explicitly. As Snaza and Weaver also indicate, posthumanism fully embraces the status of the nonhuman as real, and real here is not Lacan's Real (i.e., the Real as impossible or unsymbolizable) but the real stuff of material existence. Another way to put this is that posthumanism attends to and often embraces the findings of science while still maintaining the necessity of speculative and critical rationality to complicate, contextualize, and critique what science ignores, reifies, or cannot account for. Thus, posthumanism, and related approaches such as new materialism and speculative realism, pushes beyond the epistemological limits of language and culture that were central to so much constructivist work during the height of antihumanism. Or, to put it philosophically, they refuse to stay on the level of epistemology and instead insist on ontology. While, as Rebekah Sheldon points out, what appears to be an ontology can often be an epistemology in disguise; at their best, posthumanisms attempt to move beyond merely getting caught up in the endless circuits of representation and linguistic construction and begin to think about what exists (Sheldon 2016). Thus, they can attend to human actors as well as non-human actors such as animals, plants, ecologies, materialities, etc. Moreover, these don't just exist for humans but also in tension or in partial excess of human representation, knowledge and control.

At its best, then, posthumanism helps situate the humanities on a more materialist, yet still critical and speculative, basis. Yet this approach has drawbacks as well. For one thing, posthumanism tends to be less systematic than antihumanism. It posits materiality in all of its complexity, but it typically does not attend as often to systems of meaning, political-ecology, and political-economy with the same complexity, scope, and force that much antihumanism did. Theoretical accounts of the Anthropocene of course do this, but the concept is too often invoked rather than fully theorized. We need to think about specific instances or ecosystems of the material, the animal, and the mechanical, but we also need to think about how these link up to global systems and structures. Similarly, we need not only to think past human exceptionalism, for all the ethical and crucial ecological reasons that animal studies and theorists of the Antrhopocene have articulated, but we also need to attend to the differences between types and kinds of animals, machines, materialities, and environments, if only so we can make hard economic and ecological choices about sustainability and equality. 
At its best, posthumanism too can contribute to a newly invigorated Marxist theorizing, one that considers the way in which what Jason Moore has described as "cheap nature" has contributed to the growth of capitalism, and the way in which the integration of animals and nature into capitalism has produced what he terms a "metabolic shift" in the "world ecology" (Moore 2015). Such a Marxism might finally fully integrate ecological thinking into its already powerful economic thinking. It also might start to recognize not only the force and agency of all sorts of things (including the often dominating agency of humans of course), but also find rubrics for understanding the way in which machines, materials, plants, ecosystems, and nonhuman animals contribute to the production of value and to the ecological and economic habitats and systems we construct. Perhaps this means that we will need to construct other labor theories of value that parallel the one for human labor that Marx so eloquently articulated. But at its best, such a vision would push us to think about all the dimensions of existence, sustainability, and production in ways newly attentive to the ecological, economic and political challenges of the present, near, and distant future.

\section{Coda}

To think humanism, antihumanism, and posthumanism in tension and in relationship with each other to me promises a twenty-first-century humanities worthy of the name. This version of the humanities should not hide in various enclosures, but seek and risk encounters with knowledge and thoughts other than its own. We need to defend the humanities, but such a defense will happen in our labor and political organizing, in our willingness to be bad workers. It will happen in how we collectively recommit to the value of the humanities and convince the general public of that value. Yet we also need a humanities worthy of defending. Limiting our scope or willfully deprofessionalizing ourselves will not make us more palatable. It will only hasten our demise. Instead, the humanities should push to address and to work to solve the most pressing questions of our moment. If central to the purview of the humanities is thinking about the human, then recent developments in antihumanism and posthumanism (and even a fully critical humanism) suggest that we can't understand the human without also attend to everything with which it intersects and affects. Such a charge represents the humanities at its most visionary and necessary.

Funding: This research received no external funding.

Acknowledgments: I'd like to thank Anna Kornbluh, Nathan Snaza, and Ronald Strickland for reading different versions of this essay. They don't agree with everything here, but they absolutely made it a stronger essay.

Conflicts of Interest: The author declares no conflict of interest.

\section{References}

Adorno, Theodor W. 1973. Negative Dialectics. Translated by E. B. Ashton. London: Continuum.

Alaimo, Stacy. 2010. Bodily Natures: Science, Environment, and the Material Self. Bloomington: Indiana University Press. Armstrong, Isobel. 2000. The Radical Aesthetic. Oxford: Blackwell Publishing.

Balibar, Étienne. 1994. Masses, Classes, Ideas: Studies on Politics and Philosophy Before and after Marx. New York: Routledge. Balibar, Étienne. 1995. The Philosophy of Marx. Translated by Chris Turner. London: Verso.

Berlant, Lauren. 2011. Cruel Optimism. Durham: Duke University Press.

Best, Steven, and Sharon Marcus. 2009. Surface Reading: An Introduction. Representations 108: 1-21. [CrossRef]

Bourdieu, Pierre. 1984. Distinction: A Social Critique of the Judgment of Taste. Translated by Richard Nice. Cambridge: Harvard University Press.

Bousquet, Marc. 2008. How the University Works: Higher Education and the Low-Wage Nation. New York: New York University Press.

Brown, Wendy. 2015. Undoing the Demos: Neoliberalism's Stealth Revolution. Cambridge: MIT Press.

Canagarajah, A. Suresh. 2014. Negotiating Transnational Literacy: An Enactment. Research in the Teaching of English 48: 40-67. 
Christopher, Paul. 2018. The Toxic Meritocracy of Video Games: Why Gaming Culture is the Worst. Minneapolis: University of Minnesota Press.

Colebrook, Clare. 2014. Sex after Life Volume 2. Ann Arbor: Open Humanities Press.

Courtemanche, Eleanor. 2016. The Peculiar Success of Cultural Studies 2.0. Arcade: Literature, Humanities, and the World. Available online: http:/ / arcade.stanford.edu/blogs/peculiar-success-cultural-studies-20 (accessed on 5 June 2018).

Donoghue, Frank. 2018. The Last Professors: The Corporate University and the Fate of the Humanities, Tenth Anniversary ed. New York: Fordham University Press.

Eagleton, Terry. 2016. Materialism. New Haven: Yale University Press.

Felski, Rita. 2015. The Limits of Critique. Chicago: University of Chicago Press.

Foucault, Michel. 1972. The Archaeology of Knowledge and the Discourse on Language. Translated by A. M. Sheridan Smith. New York: Pantheon Books.

Foucault, Michel. 2010. The Birth of Biopolitics: Lectures at the College de France, 1978-1979. Translated by Graham Burchell. New York: Picador.

Foucault, Michel, and Gilles Deleuze. 2006. Intellectuals and Power: A Conversation between Michel Foucault and Gilles Deleuze. Available online: https:/ /libcom.org/library/intellectuals-power-a-conversation-betweenmichel-foucault-and-gilles-deleuze (accessed on 6 June 2018).

Ginsberg, Benjamin. 2011. The Fall of the Faculty: The Rise of the All Administrative University and Why It Matters. Oxford: Oxford University Press.

Hall, Stuart. 2008. Encoding, Decoding. In Cultural Studies: An Anthology, 1st ed. Edited by Michael Ryan. Oxford: Blackwell, pp. 907-16.

Haraway, Donna. 1998. Situated Knowledges: The Science Question in Feminism and the Privilege of Partial Perspective. Feminist Studies 14: 575-99. [CrossRef]

Harman, Graham. 2012. The Well-Wrought Broken Hammer. New Literary History 43: 183-203. [CrossRef]

Harney, Stefano, and Fred Moten. 2013. The Undercommons: Fugitive Planning and Black Study. Oakland: AK Press. Harvey, David. 2005. A Brief History of Neoliberalism. Oxford: Oxford UP.

Horkheimer, Max, and Theodor W. Adorno. 1999. Dialectic of Enlightenment. Translated by John Cumming. New York: Continuum.

Jay, Paul. 2014. The Humanities "Crisis" and the Future of Literary Studies. New York: Palgrave Macmillan.

Kornbluh, Anna. 2017. We Have Never Been Critical: Toward the Novel as Critique. Novel 50: 397-408. [CrossRef] Latour, Bruno. 1993. We Have Never Been Modern. Cambridge: Harvard University Press.

Latour, Bruno. 2004. Why Has Critique Run Out of Steam? From Matters of Fact to Matters of Concern. Critical Inquiry 30: 225-48. [CrossRef]

Levine, Caroline. 2017. Forms: Whole, Rhythm, Hierarchy, Network. Princeton: Princeton University Press.

Marx, Karl. 1978. Economic and Philosophic Manuscripts of 1844. In The Marx-Engels Reader, 2nd ed. Edited by Robert C. Tucker. New York: W.W. Norton, pp. 66-125.

Meillassoux, Quentin. 2008. After Finitude: An Essay on the Necessity of Contingency. Translated by Ray Brassier. London: Continuum.

Moore, Jason. 2015. Capitalism in the Web of Life: Ecology and the Accumulation of Capital. London: Verso.

Morton, Timothy. 2013. Hyperobjects: Philosophy after the End of the World. Minneapolis: University of Minnesota Press. Ngai, Sianne. 2012. Our Aesthetic Categories: Zany, Cute, Interesting. Cambridge: Harvard University Press.

Radway, Janice. 1991. Reading the Romance: Women, Patriarchy, and Popular Literature, 2nd ed. Chapel Hill: University of North Carolina Press.

Readings, Bill. 1996. The University in Ruins. Cambridge: Harvard University Press.

Searls, Damion. 2008. Manifesto: New Aestheticism. The Quarterly Conversation. Available online: http:/ / quarterlyconversation.com/manifesto-new-aestheticism (accessed on 13 July 2018).

Sedgwick, Eve. 2003. Touching Feeling: Affect, Pedagogy, Performativity. Durham: Duke Uiversity Press.

Sheldon, Rebekah. 2016. Dark Correlationism: Mysticism, Magic, and the New Realisms. Symplokē 24: 137-53. [CrossRef] 
Snaza, Nathan, and John Weaver. 2014. Introduction: Education and the Posthuman Turn. In Posthumanism and Educational Research. Edited by Nathan Snaza and John Weaver. New York: Routledge, vol. 1, pp. 1-15.

Žižek, Slavoj. 1989. The Sublime Object of Ideology. London: Verso.

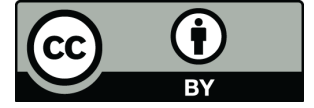

(C) 2018 by the author. Licensee MDPI, Basel, Switzerland. This article is an open access article distributed under the terms and conditions of the Creative Commons Attribution (CC BY) license (http:// creativecommons.org/licenses/by/4.0/). 